\title{
Survey Pengetahuan dan Sikap Terhadap Kekerasan dalam Rumah Tangga pada Perempuan Dewasa di Kecamatan Sukoharjo Kabupaten Pringsewu
}

\author{
$\underline{\text { Adi Prasandi }{ }^{1}, \text { Hasni Diana }}{ }^{2}$ \\ 1,2 Universitas Aisyah Pringsewu Lampung \\ Jl. A. Yani 1A Tambahrejo Kecamatan Gadingrejo Kabupaten Pringsewu Lampung 35372 \\ e-mail: ${ }^{* 1}$ adiprasandi96@gmail.com, 2hasnidiana@aisyah.ac.id
}

\begin{abstract}
The number of domestic violence to women increases every year. This study purpose was to provide an overview about knowledge and attitudes of adult women about domestic violence in Sukoharjo IV Village, Pringsewu, Lampung. The research design was simple descriptive with univariate analysis methods. Total samples were 93 respondents; determined by quota sampling technique. The results showed $64.5 \%$ of respondents had low level of knowledge and $54.8 \%$ of respondents have bad attitudes toward domestic violence. Less knowledge caused by inadequate resources, experienced, and financial. Significant others' experiences, patriarchy, and limited media access influence bad attitude. To prevent domestic violence, the health service providers should provide adequate health education.
\end{abstract}

Keywords: Burnout; Adult Woman, Attitudes, Domestic violence, Knowledge

\begin{abstract}
Abstrak. Angka kejadian KDRT pada perempuan dewasa terus meningkat setiap tahunnya. Penelitian ini bertujuan untuk memberikan gambaran pengetahuan dan sikap perempuan dewasa tentang Kekerasan Dalam Rumah Tangga di Desa Sukoharjo IV Kabupaten Pringsewu Lampung. Desain penelitian yang digunakan deskriptif sederhana dengan metode analisis univariat. Jumlah sampel sebanyak 93 responden, ditentukan dengan teknik quota sampling. Hasil penelitian menunjukkan $64,5 \%$ responden memiliki pengetahuan kurang dan 54,8\% responden memiliki sikap negatif terhadap KDRT. Pengetahuan kurang karena kurangnya sumber informasi, tidak berpengalaman, dan finansial terbatas. Sikap negatif dipengaruhi pengalaman significant others, budaya patriarki, dan keterbatasan akses media. Penyedia layanan kesehatan hendaknya memberikan penyuluhan dan konseling mengenai KDRT.
\end{abstract}

Kata kunci: Kekerasan Dalam Rumah Tangga (KDRT), pengetahuan, perempuan dewasa, sikap

\section{Pendahuluan}

Kekerasan Dalam Rumah Tangga (KDRT) merupakan salah satu masalah kesehatan perempuan yang banyak terjadi di Indonesia. Definisi KDRT menurut Undang-Undang Republik Indonesia Nomor 23 Tahun 2004 adalah "Setiap perbuatan terhadap seseorang terutama perempuan, yang berakibat timbulnya kesengsaraan atau penderitaan secara fisik, seksual, psikologis, dan atau penelantaran rumah tangga termasuk ancaman untuk melakukan perbuatan, pemaksaan, atau perampasan kemerdekaan secara melawan hukum dalam lingkup rumah tangga" (Triwijati, 2007).

Kejadian KtP di Indonesia tahun 2016 sebesar 259.150 kasus meningkat menjadi 348.466 kasus pada 2017 dan per agustus 2018 jumlah kekerasan tercatat sebesar 7.548 kasus. Jenis kekerasan tertinggi 
adalah kekerasan dalam rumah tangga (KDRT)/ranah personal (RP) sebesar 71\% (9.609). Posisi kedua adalah ranah komunitas/publik sebesar 26\% (3.528) dan disusul KtP di ranah negara sebesar 1,8\% (217). Pada ranah KDRTRP kekerasan yang paling menonjol adalah kekerasan fisik 3.982 kasus (41\%), menempati peringkat pertama disusul kekerasan seksual kasus 2.979 ( 31\%), psikis 1.404 (15\%) dan ekonomi 1.244 kasus (13\%) (Komisi Nasional Anti Kekerasan Terhadap Perempuan, 2018).

Pada kekerasan di ranah rumah tangga/relasi personal, kekerasan terhadap istri (KTI) menempati peringkat pertama 5.167 kasus (54\%), disusul kekerasan dalam pacaran 1.873 kasus (19\%), kekerasan terhadap anak perempuan 2.227 kasus (23\%) dan sisanya kekerasan mantan suami, kekerasan mantan pacar, serta kekerasan terhadap pekerja rumah tangga. Peta korban KtP di ranah personal/KDRT dan komunitas yang dapat diidentifikasi melalui umur adalah perempuan yang sedang puncak produktif dari segi sosial biologis. (Komisi Nasional Anti Kekerasan Terhadap Perempuan, 2018).

Ranah yang paling berisiko bagi perempuan, yaitu kekerasan dalam ranah personal, yaitu diantaranya perkawinan atau dalam rumah tangga (KDRT), dan dalam hubungan personal (hubungan pribadi/pacaran) yaitu sebesar 71\% (Komisi Nasional Anti Kekerasan Terhadap Perempuan, 2018). Kekerasan terhadap perempuan dalam ranah pribadi terjadi dalam berbagai bentuk seperti kekerasan terhadap istri (KTI) 5.167, kekerasan dalam pacaran (KDP) sebesar 1,873, kekerasan terhadap anak perempuan (KTAP) berdasarkan umur anak 2,27, kekerasan yang dilakukan oleh mantan suami dan mantan pacar 155 kekerasan yang terjadi pada pekerja rumah tangga 140, dan ranah personal lainnya. Bentuk kekerasan terbanyak adalah fisik (41\%), dan seksual sebanyak (31\%). Kekerasan seksual menjadi terbanyak kedua yang dilaporkan, dan menunjukkan rumah dan relasi pribadi belum menjadi tempat yang aman bagi perempuan (Komisi Nasional Anti Kekerasan Terhadap Perempuan, 2018).

Kasus KDRT pada perempuan terjadi dalam berbagai bentuk tindak kekerasan dan memberikan dampak negatif bagi korbannya. Bentuk kekerasan yang terjadi ditemukan oleh Komnas Perempuan pada tahun 2011 yaitu sebanyak 4\% atau 3.753 kasus dari total 105.103 kasus kekerasan terhadap perempuan berupa kasus kekerasan seksual diantaranya kasus perkosaan, eksploitasi seksual, pelecehan seksual, dan kontrol seksual (Tarida, 2011). Dampak KDRT terlihat pada Data Women Crisis Center (WCC) pada tahun 2007 yang mencatat 87\% dari perempuan korban kekerasan yang mengakses layanan WCC mengalami KDRT dan sembilan dari sepuluh perempuan korban kekerasan yang didampingi WCC mengalami gangguan kesehatan jiwa, 12 orang pernah mencoba bunuh diri, dan 13,12\% menderita gangguan kesehatan reproduksi (Kolibonso, 2010). Dampak lain dari KDRT diperoleh dari data Susenas tahun 2006 dalam Kebijakan Perlindungan Perempuan 2010 sampai 2014 yaitu 71\% perempuan korban KDRT mengalami sakit hati, 7\% mengalami stress, dan 5\% menderita luka cacat (Kementrian Negara Pemberdayaan Perempuan, 2010). Data-data tersebut menunjukkan bahwa KDRT mayoritas terjadi pada perempuan.

KDRT banyak terjadi pada perempuan karena berbagai faktor. Faktor pertama berasal dari pihak laki-laki dimana laki-laki yang memiliki kekuatan fisik lebih besar dapat dengan mudah menganiaya perempuan yang memiliki kekuatan fisik lebih lemah. Faktor lain adalah faktor budaya yang menguntungkan pihak laki- laki seperti budaya patriarki di Indonesia. Budaya patriarki di Indonesia menunjukkan bahwa laki-laki berada dalam posisi dominan atau superior dibandingkan dengan perempuan dan menjadikan laki-laki memiliki kekuasaan lebih tinggi di dalam keluarga (Kurniasih, 2007). Posisi laki-laki yang lebih tinggi dalam budaya patriarki dan konflik yang terjadi dalam rumah tangga yang tidak terselesaikan dapat memicu adanya tindak kekerasan. Hal tersebut dapat menjadi alasan untuk menjadikan perempuan sebagai korban kekerasan.

Faktor lain penyebab KDRT berasal dari diri perempuan sendiri. Mardiana (2012) dalam situs detik.com menuliskan bahwa Ketua Tim Penggerak (TP) PKK Provinsi Jawa Barat, Netty Prasetiyani Heryawan menilai minimnya pemahaman perempuan tentang Kekerasan Dalam Rumah Tangga 
(KDRT) menjadi salah satu penyebab masih tingginya kejadian KDRT di Jawa Barat. Hal serupa ditemukan berdasarkan studi kualitatif yang dilakukan Novitasari (2010) pada warga desa Rasabou menyebutkan gambaran kekerasan yang terjadi di desa Rasabou yaitu berupa kekerasan fisik, kekerasan psikis, kekerasan ekonomi dan kekerasan seksual dengan faktor yang melatarbelakangi terjadinya KDRT tersebut antara lain tingkat pengetahuan yang rendah, anggapan KDRT sudah menjadi budaya, dan pernikahan dini. Sikap korban KDRT dapat terlihat dari penelitian lain yang dilakukan oleh Fachrina dan Anggraini (2007) yang menyebutkan mayoritas responden mengalami KDRT secara fisik (70\%), emosional dan ekonomi masing- masing 57,14\% serta seksual (66,66\%) memilih sikap diam atau pasrah saja, meskipun hampir keseluruhan responden menyatakan bahwa tindakan KDRT tersebut merupakan tindakan yang tidak wajar. Hal tersebut mengindikasikan bahwa pengetahuan yang rendah dan sikap pasrah dapat menjadi penyebab KDRT.

Beberapa penelitian terkait pengetahuan dan sikap terhadap KDRT telah dilakukan. Penelitian mengenai pengetahuan dilakukan Sari (2008) dan Risna (2009). Penelitian yang dilakukan Sari (2008) pada ibu rumah tangga di Kabupaten Langkat menunjukkan bahwa sebanyak 33 orang (55,9\%) dari 59 responden kurang mengetahui dampak kekerasan. Penelitian tersebut juga menunjukkan bahwa KDRT yang dilakukan di rumah berakibat pada kesehatan reproduksi. Hasil penelitian yang dilakukan oleh Risna dkk. (2009) mengenai tingkat pengetahuan ibu rumah tangga tentang KDRT terhadap istri di RW 08 Kelurahan Pondok Cina, Beji, Depok menyebutkan mayoritas responden memiliki pengetahuan yang tinggi (58,1\%). Kedua penelitian ini hanya dilakukan pada ibu rumah tangga saja dan tidak dilakukan pada perempuan umumnya. Kedua penelitian tersebut juga membahas pengetahuan ibu rumah tangga berdasarkan materi tentang definisi, bentuk-bentuk, dan dampak KDRT, namun tidak membahas mengenai karakteristik responden yang dapat memengaruhi pengetahuan itu sendiri. Perbedaan kedua penelitian tersebut terletak pada tempat penelitian dimana penelitian Sari (2008) dilakukan di pedesaan dan Risna dkk. (2009) di perkotaan. Penelitian Sari (2008) menggambarkan pengetahuan ibu rumah tangga di pedesaan namun dari satu kabupaten hanya diambil 59 ibu rumah tangga sebagai responden.

Penelitian mengenai sikap terhadap KDRT dilakukan Marshall dan Furr (2010) pada perempuan di Turki. Hasil penelitian tersebut menunjukkan bahwa perempuan yang memiliki ukuran rumah tangga yang lebih besar, memegang nilai-nilai patriarki, menikah di usia yang lebih muda, menetap di daerah pedesaan, dan menerima uang pengantin (lamaran), membenarkan setidaknya satu situasi dimana suami dapat memukul istri mereka. Penelitian ini menekankan pada faktor yang membuat seorang perempuan membenarkan satu bentuk KDRT, namun tidak memberikan gambaran sikap perempuan terhadap KDRT pada umumnya.

Penelitian mengenai pengetahuan dan sikap terhadap KDRT pada perempuan dewasa di pedesaan dengan budaya patriarki yang cukup kental perlu dilakukan. Salah satu daerah dimana budaya patriarki sangat kental dalam lingkungan pedesaan berada pada wilayah Desa Sukoharjo IV Kabupaten Pringsewu Lampung. Studi pendahuluan yang peneliti lakukan di kawasan ini menunjukkan beberapa perempuan dewasa tidak mengetahui tentang KDRT. Beberapa perempuan dewasa di kawasan ini menganggap KDRT hanya berupa kekerasan fisik berupa pemukulan dan penganiayaan terhadap istri. Kekerasan terhadap anak dan orang lain yang tinggal serumah juga dianggap bukan KDRT pada beberapa perempuan dewasa. Beberapa perempuan dewasa dalam studi pendahuluan ini juga tidak mengerti bagaimana harus bersikap terhadap KDRT. Perempuan dewasa di kawasan ini memiliki keanekaragaman demografi yang menarik untuk diteliti. Budaya patriarki terlihat cukup kental di wilayah ini dimana perempuan tunduk pada semua perkataan laki-laki. Hal-hal tersebut menyebabkan perlu diadakannya penelitian mengenai gambaran pengetahuan dan sikap perempuan dewasa tentang kekerasan dalam rumah tangga di Desa Sukoharjo IV Kabupaten Pringsewu Lampung. 


\section{Metode}

\section{Partisipan penelitian}

Populasi pada penelitian ini adalah seluruh perempuan dewasa yang sudah menikah yang berusia 21 sampai 60 tahun dan bertempat tinggal di Desa Sukoharjo IV Kabupaten Pringsewu Lampung yang terdiri dari tiga dusun dengan jumlah 855 orang (Data Kelurahan Sukoharjo IV, 2019). Jumlah sampel ditentukan berdasarkan jumlah dusun dengan masing-masing dusun diambil sebanyak 50 responden sehingga jumlah total sampel sebanyak 150 orang. Pemilihan sampel menggunakan teknik penarikan sampel tidak acak (non-probability sampling) secara quota sampling.

\section{Prosedur penelitian}

Penelitian ini dilakukan di Desa Sukoharjo IV Kabupaten Pringsewu Lampung yang berlangsung antara bulan Mei hingga Juli 2019. Metode pengumpulan data yang digunakan adalah dengan menggunakan sistem penyebaran kuesioner. Peneliti menjelaskan identitas peneliti dan maksud penyebaran kuesioner. Peneliti meminta responden yang memenuhi kriteria inklusi untuk membaca informed consent.

\section{Instrumen}

Alat pengumpulan data pada penelitian ini menggunakan kuesioner yang mengacu pada teori yang sesuai dengan dasar penelitian. Kuesioner yang digunakan dalam penelitian ini terdiri dari tiga bagian. Bagian pertama berisi 4 pertanyaan yang berkaitan dengan data demografi atau karakteristik responden. Pertanyaan yang diajukan pada karakteristik responden adalah rentang usia responden, tingkat pendidikan, pekerjaan, dan status pernikahan. Bagian kedua terdiri dari 29 pernyataan yang berkaitan dengan pengetahuan perempuan dewasa tentang KDRT yang terdiri dari pertanyaan mengenai pengertian KDRT, bentuk-bentuk KDRT, dampak KDRT dan tindakan yang dilakukan ketika mengalami KDRT. Bagian ketiga kuesioner berisi 15 pertanyaan mengenai sikap perempuan dewasa terhadap KDRT.

\section{Analisis data}

Analisis data pada penelitian ini adalah menggunakan analisis univariat untuk mengetahui gambaran pengetahuan perempuan dewasa tentang KDRT di Desa Sukoharjo IV Kabupaten Pringsewu Lampung. Analisis univariat dalam penelitian ini menggambarkan frekuensi dari seluruh variabel yang diteliti. Variabel yang dimaksud yaitu pengetahuan dan sikap perempuan dewasa tentang KDRT. Pengetahuan responden dibuat menjadi tiga kategori dengan skor $76 \%$ sampai $100 \%$ untuk pengetahuan baik, skor $56 \%$ sampai $75 \%$ untuk pengetahuan cukup dan kurang dari 55\% untuk pengetahuan kurang (Arikunto, 2004). Pengetahuan baik disini jika responden mengetahui semua materi tentang KDRT, pengetahuan cukup jika responden hanya mengetahui sebagian materi tentang KDRT dan pengetahuan kurang jika responden hanya mengetahui sedikit materi tentang KDRT. Pembagian kategori untuk variabel sikap yaitu skor 55\% sampai 100\% untuk sikap baik dan skor kurang dari 55\% untuk sikap buruk (Arikunto, 2004). Sikap baik pada responden dimaksudkan jika peneliti berani melawan tindak KDRT sedangkan sikap buruk jika responden hanya pasrah terhadap KDRT. Peneliti juga menghitung 
gambaran pengetahuan dan sikap responden tentang KDRT berdasarkan karakteristik masing-masing responden.

\section{Hasil Penelitian}

Tabel 1. Karakteristik Responden

\begin{tabular}{lrr}
\hline \multicolumn{1}{c}{ Variabel } & Frekuensi (n) & Presentase (\%) \\
\hline Usia & & 27,7 \\
$21-27$ tahun & 21 & 14 \\
$28-32$ tahun & 39 & 25,8 \\
$33-39$ tahun & 53 & 35,5 \\
$40-60$ tahun & & 24,7 \\
\hline Pendidikan & 37 & 28 \\
SD & 42 & 40,9 \\
SMP & 61 & 6,4 \\
SMA & 10 & \\
Perguruan Tinggi & & 95,6 \\
\hline Pekerjaan & 143 & 4,4 \\
Ibu rumah tangga & 7 & 93,5 \\
Berkerja diluar rumah & & 6,5 \\
\hline Status Pernikahan & 140 & 10 \\
Menikah & & \\
janda & & \\
\hline
\end{tabular}

Karakteristik responden yang diteliti dalam penelitian ini adalah usia, tingkat pendidikan, pekerjaan, dan status pernikahan. Tabel 1 memberikan gambaran mayoritas responden berada pada usia 40 sampai 60 tahun sebanyak 35,5\%. Mayoritas responden adalah lulusan SMA, yaitu sebanyak 40,9 persen. 95,6 persen responden merupakan ibu rumah tangga. Mayoritas responden memiliki status menikah sebanyak $93,5 \%$.

Tabel 2. Distribusi Frekuensi Responden berdasarkan pengetahuan dan Sikap terhadap KDRT

\begin{tabular}{|c|c|c|}
\hline Variabel & Frekuensi (n) & Presentase (\%) \\
\hline \multicolumn{3}{|l|}{ Pengetahuan } \\
\hline Baik & 35 & 23,7 \\
\hline Cukup & 18 & 11,8 \\
\hline Kurang & 97 & 64,5 \\
\hline \multicolumn{3}{|l|}{ Sikap } \\
\hline Baik & 68 & 45,2 \\
\hline Buruk & 82 & 54,8 \\
\hline
\end{tabular}

Gambaran pengetahuan responden tentang Kekerasan Dalam Rumah Tangga (KDRT) disajikan dalam diagram di bawah ini. Tabel 2 menggambarkan pengetahuan rendah tentang KDRT dimiliki mayoritas responden (64,5\%). Sebagian besar responden memiliki sikap buruk terhadap KDRT yaitu berjumlah 51 responden $(54,8 \%)$. 


\section{Pengetahuan dan Sikap Responden tentang KDRT Berdasarkan Karakteristik Responden \\ Usia}

Gambar 1 menggambarkan bahwa mayoritas pengetahuan kurang dimiliki oleh responden berusia 33 sampai 39 tahun $(70,8 \%)$ dan pengetahuan baik dimiliki responden berusia 40 sampai 60 tahun $(27,3 \%)$.

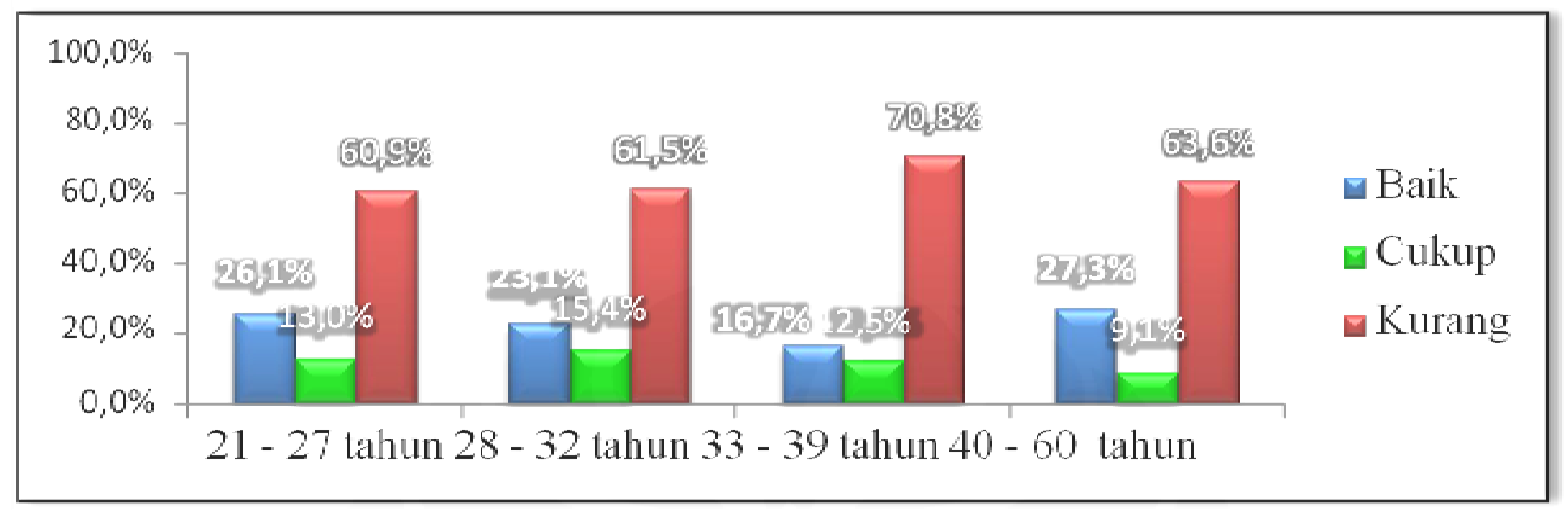

\section{Gambar 1}

Distribusi Frekuensi Pengetahuan Responden tentang KDRT Berdasarkan Karakteristik Usia

Gambar 2 memberikan gambaran mayoritas sikap positif terhadap KDRT dimiliki oleh responden berusia 33 sampai 39 tahun $(54,2 \%)$ sedangkan sikap buruk dimiliki responden berusia 28 sampai 32 tahun $(61,5 \%)$.

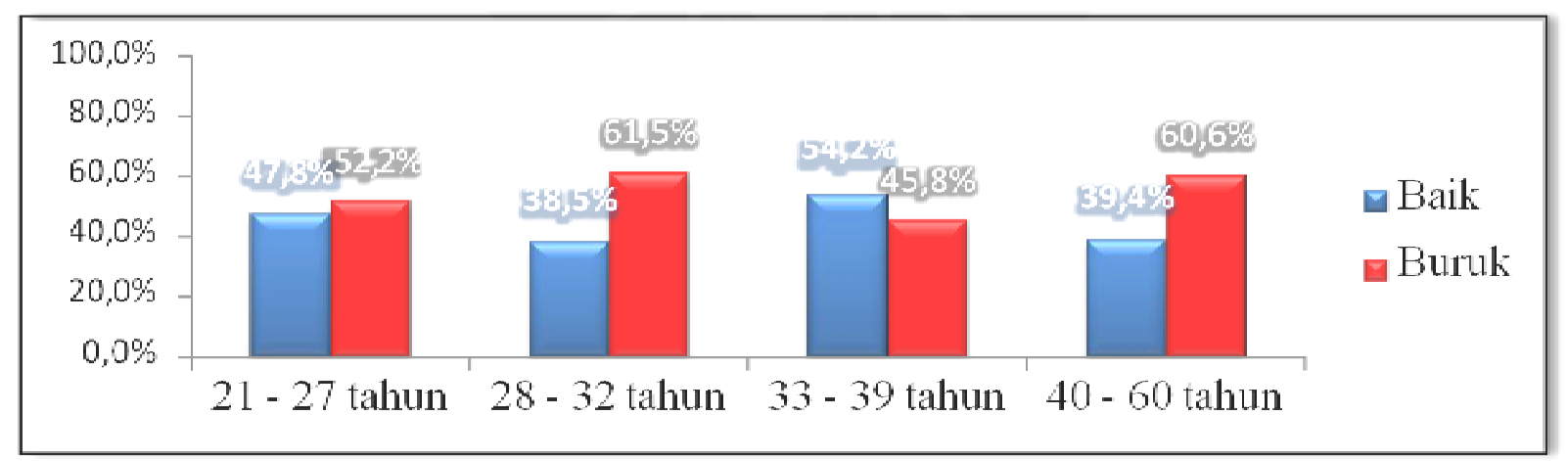

\section{Gambar 2}

Distribusi Frekuensi Sikap Responden tentang KDRT Berdasarkan Karakteristik Usia

\section{Tingkat Pendidikan}

Gambar 3 memberikan gambaran mayoritas pengetahuan baik dimiliki oleh responden lulusan SD $(30,4 \%)$ sedangkan pengetahuan kurang dimiliki responden lulusan perguruan tinggi $(66,8 \%)$. 


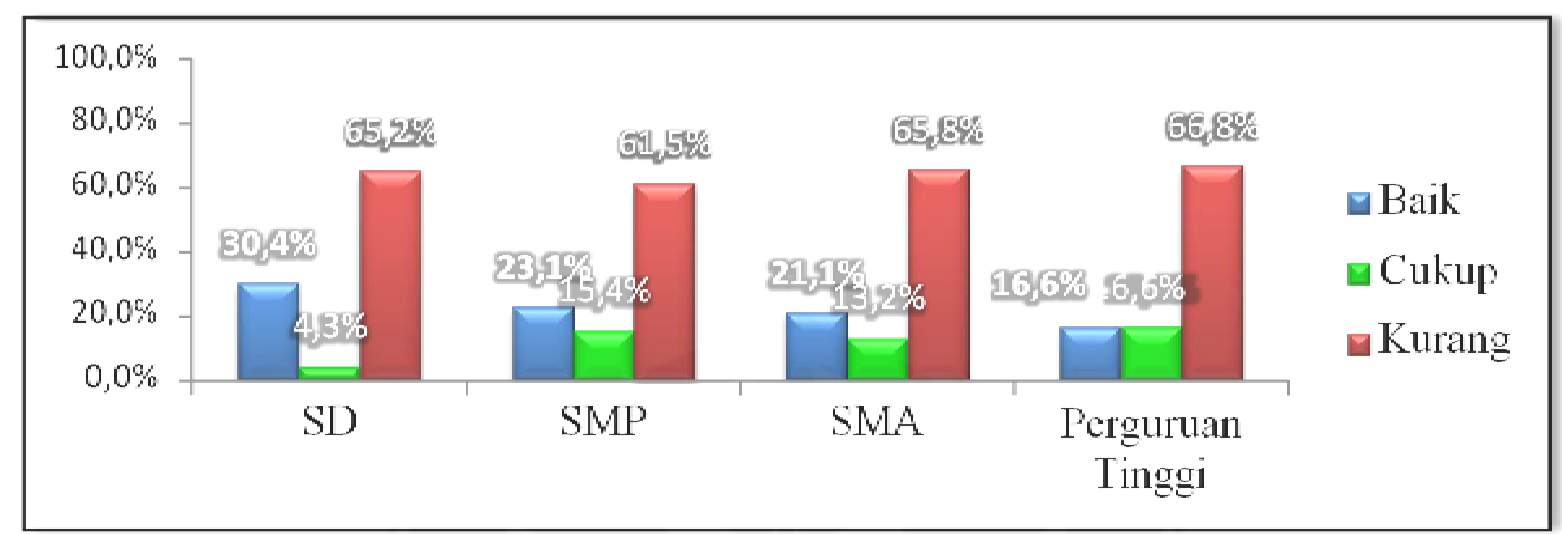

\section{Gambar 3}

Pengetahuan Responden tentang KDRT Berdasarkan Karakteristik Tingkat Pendidikan

Gambar 4 memberikan gambaran sikap baik terhadap KDRT dimiliki oleh mayoritas responden lulusan perguruan tinggi (60\%) dan sikap buruk dimiliki mayoritas responden lulusan SMA (65,8\%).

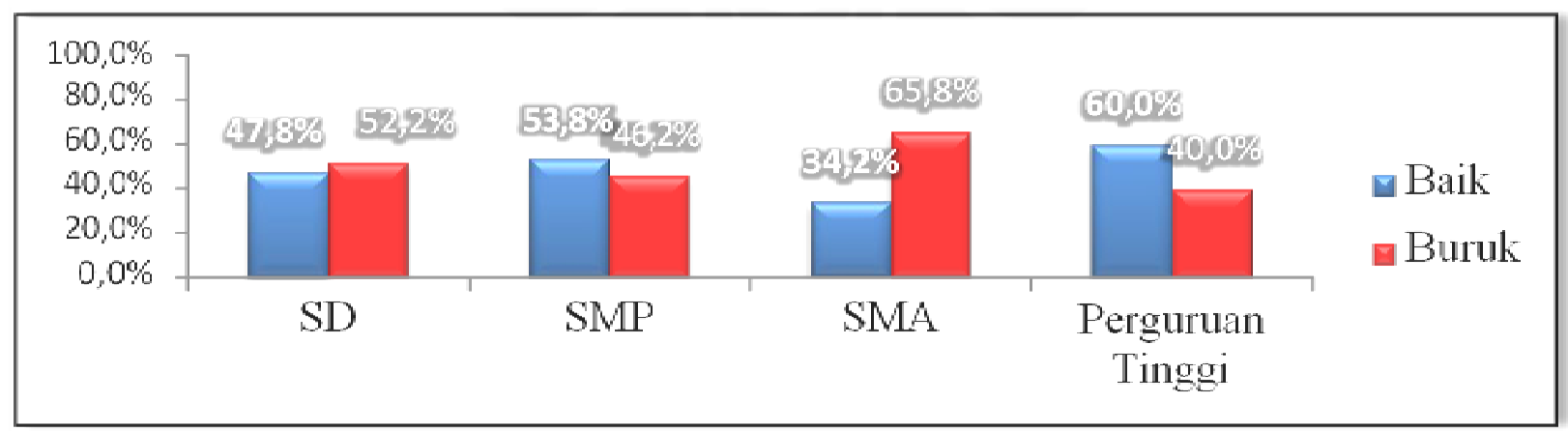

\section{Gambar 4}

Sikap Responden terhadap KDRT Berdasarkan Tingkat Pendidikan

\section{Pekerjaan}

Gambar 5 menggambarkan mayoritas pengetahuan baik (75\%) dan kurang (25\%) tentang KDRT dimiliki oleh responden yang bekerja di luar rumah.

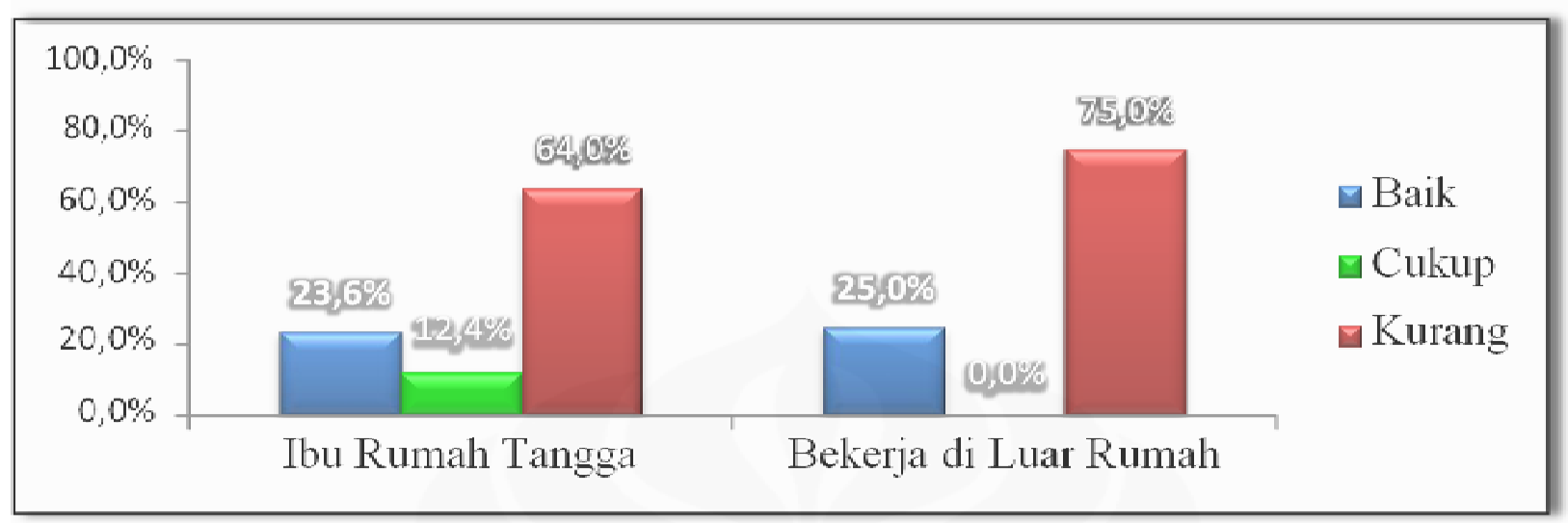

\section{Gambar 5}

Pengetahuan Responden terhadap KDRT Berdasarkan Karakteristik Pekerjaan 
Gambar 6 menggambarkan mayoritas sikap baik terhadap KDRT dimiliki oleh responden yang bekerja di luar rumah (50\%) sedangkan sikap buruk dimiliki mayoritas responden ibu rumah tangga $(55,1 \%)$.

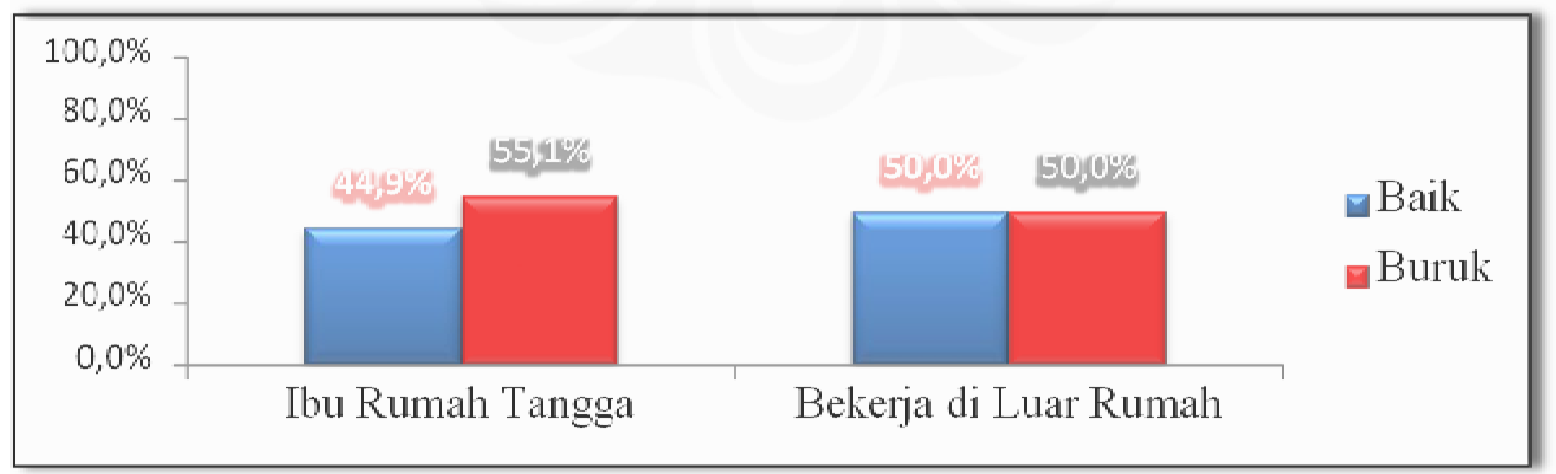

Gambar 6. Distribusi Frekuensi Sikap Responden terhadap KDRT Berdasarkan Karakteristik Pekerjaan

Status Pernikahan

Gambar 7 menggambarkan pengetahuan baik dimiliki oleh mayoritas responden janda (40\%) sedangkan pengetahuan kurang dimiliki mayoritas responden menikah $(64,4 \%)$.

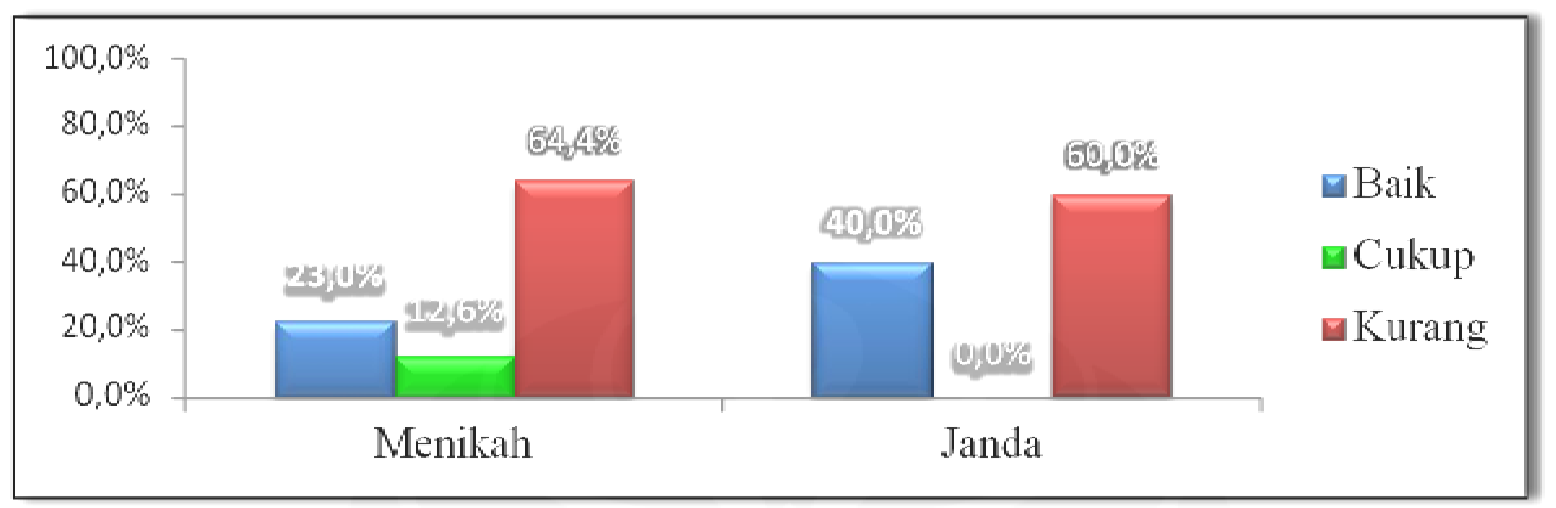

Gambar 7. Pengetahuan Responden terhadap KDRT Berdasarkan Status Pernikahan

Gambar 8 menggambarkan sikap baik terhadap KDRT dimiliki oleh mayoritas responden menikah (46\%) sedangkan sikap buruk dimiliki mayoritas responden janda $(60 \%)$.

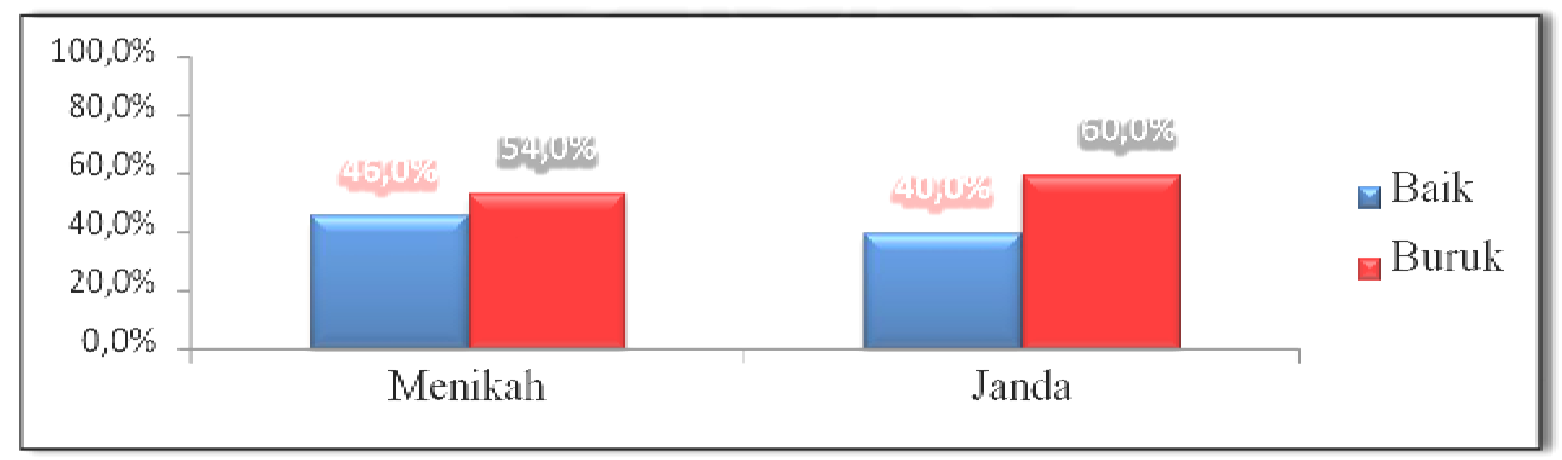

Gambar 8. Sikap Responden terhadap KDRT Berdasarkan Status Pernikahan 


\section{Pengetahuan Perempuan Dewasa tentang KDRT}

Hasil penelitian ini menggambarkan bahwa mayoritas responden memiliki pengetahuan kurang (64,5\%). Hal ini dimungkinkan terjadi pada perempuan dewasa di Desa Sukoharjo IV Kabupaten Pringsewu Lampung karena memiliki keyakinan bahwa KDRT hanya merupakan tindak kekerasan fisik yang dilakukan suami kepada istri. Kondisi sosial yang beranggapan bahwa KDRT bukan merupakan hal yang pantas untuk diceritakan kepada orang lain turut memengaruhi pengetahuan perempuan dewasa. Finansial perempuan dewasa di kawasan ini bergantung pada penghasilan suami yang kebanyakan memiliki penghasilan terbatas. Hal tersebut membuat perempuan dewasa merasa kurang perlu untuk mengakses sumber informasi mengenai KDRT yang tentunya memerlukan biaya tambahan. Sumber informasi yang dimiliki perempuan dewasa di kawasan pedesaan ini hanya sebatas pada televisi dan radio. Majalah, koran, dan internet sulit di jangkau karena letaknya jauh dari wilayah RW 10. Penyuluhan mengenai KDRT belum pernah diadakan sehingga perempuan dewasa kurang sadar bahwa informasi mengenai KDRT itu penting. Hal ini sesuai dengan faktor yang memengaruhi pengetahuan menurut Notoatmodjo, yaitu dipengaruhi oleh beberapa faktor. Notoatmodjo (2007), yaitu pengalaman, tingkat pendidikan, keyakinan, sosial budaya, penghasilan, dan fasilitas atau media informasi.

Kondisi pengetahuan mengenai KDRT di kawasan pedesaan ini berbeda dengan kondisi di perkotaan. Hasil penelitian yang dilakukan oleh Risna et al (2009) mengenai tingkat pengetahuan ibu rumah tangga tentang KDRT terhadap istri di RW 08 Kelurahan Pondok Cina, Beji, Depok menyebutkan mayoritas responden memiliki pengetahuan yang tinggi $(58,1 \%)$. Hal ini dapat terjadi karena ibu rumah tangga di perkotaan lebih mudah dalam mengakses informasi sehingga lebih sadar terhadap KDRT.

\section{Sikap Perempuan Dewasa tentang KDRT}

Hasil penelitian ini juga menunjukkan bahwa sebagian besar responden (54,8 \%) memiliki sikap buruk terhadap KDRT. Hal ini dimungkinkan bahwa pembentukan sikap perempuan dewasa terhadap KDRT dipengaruhi nilai-nilai agama yang dianut sebagian besar perempuan dewasa di wilayah ini juga mengajarkan bahwa laki-laki merupakan pemimpin bagi kaum perempuan. Hal tersebut diperkuat dengan pengalaman dari orang lain yang dianggap penting (significant others) seperti ibu, bapak, suami, dan kerabat dekat juga. Orang lain yang dianggap penting tersebut menanamkan budaya patriarki dan subordinasi dimana laki-laki berada pada posisi dominan sebagai kepala keluarga sehingga memiliki kekuasaan lebih tinggi daripada perempuan. Perempuan dewasa di wilayah ini juga mengalami keterbatasan dalam mengakses media massa sehingga tidak mendapat informasi tambahan bagaimana seharusnya perempuan menyikapi KDRT. Pendapat ini diperkuat dengan hal yang disampaikan Rahayuningsih (2008), yaitu pembentukan sikap dapat dipengaruhi oleh beberapa faktor, diantaranya pengalaman, kebudayaan, orang lain yang dianggap penting (significant other), media massa, institusi atau lembaga pendidikan dan agama, dan faktor emosional (Rahayuningsih, 2008).

Penelitian lain yang juga menunjukkan bahwa budaya patrarki dan wilayah pedesaan dapat memengaruhi pembentukan sikap dilakukan oleh Marshall dan Furr (2010) pada perempuan di Turki. Hasil penelitian tersebut menunjukkan bahwa perempuan yang memiliki ukuran rumah tangga yang lebih besar, memegang nilai-nilai patriarki, menikah di usia yang lebih muda, menetap di daerah pedesaan, dan menerima uang pengantin (lamaran), membenarkan setidaknya satu situasi dimana suami dapat memukul istri mereka. Penelitian tersebut menyimpulkan ideologi patriarki yang menciptakan gagasan ideal dari "maskulinitas hegemonik" dan "menekankan feminitas" sebagai alasan 
bagi perempuan untuk mengalah. "Maskulinitas hegemonik" adalah dominasi laki-laki yang tidak hanya kekuatan fisik namun juga ke dalam praktik budaya dan kelembagaan serta bidang lain seperti pembagian kerja di rumah sedangkan "menekankan feminitas adalah bentuk feminitas yang sesuai dengan kondisi subordinasi perempuan dan "berorientasi mengakomodasi kepentingan dan keinginan manusia" (Connel, 1987, dalam Marshall dan Furr, 2010). Status istri yang lebih rendah, khususnya dalam rumah tangga dan pola interaksi seksual, dapat menghasilkan keyakinan pada seorang perempuan bahwa ketika menantang otoritas suaminya, perempuan tidak mematuhi feminitas ideal ini (Marshall dan Furr, 2010).

\section{Pengetahuan dan Sikap Responden tentang KDRT Berdasarkan Usia}

Hasil penelitian ini menunjukkan bahwa mayoritas pengetahuan kurang dimiliki oleh responden berusia 33 sampai 39 tahun $(70,8 \%)$ dan pengetahuan baik paling banyak dimiliki responden berusia 40 sampai 60 tahun (27,3\%). Hal ini sesuai dengan teori perkembangan Levinson (1978, dalam Potter dan Perry, 2006) bahwa usia 40 sampai 60 tahun merupakan tahun keberhasilan dimana seorang perempuan dewasa sudah memiliki pengaruh maksimal, membimbing dan menilai diri sendiri. Perempuan dewasa rentang usia ini telah berhasil membuat evaluasi diri dari kehidupan berumah tangga sehingga mampu mengintegrasikan pengetahuan dari pengalaman, keyakinan, dan sumber informasi yang diterima.

Hal ini sesuai dengan tahap perkembangan Piaget bahwa pada masa ini seseorang dapat menggunakan semua kemampuan kognitif dari tahap perkembangan terdahulu (DeLaune dan Ladner, 2002). Penelitian yang sesuai dengan konsep ini dilakukan oleh Hansson, et.al (2008) dengan hasil bahwa bagian dari pengaruh negatif pada peningkatan usia terhadap kemampuan umum dapat dikompensasikan dengan peningkatan domain pengetahuan yang relevan.

Hasil penelitian menunjukkan bahwa sikap perempuan dewasa terhadap KDRT pada penelitian ini mayoritas baik pada usia 33 sampai 39 tahun (54,2\%) dan buruk pada usia 28 sampai 32 tahun (61,5\%). Hal ini dapat dijelaskan melalui fase perkembangan menurut Levinson (1978, dalam Potter dan Perry, 2006). Levinson mengidentifikasi rentang usia 28 sampai 32 tahun merupakan masa transisi dimana seorang perempuan dewasa secara besar-besaran memodifikasi aktivitas kehidupannya dan memikirkan tujuan masa depan. Perempuan pada masa ini mengalami peralihan menuju tahap kedewasaan sehingga cenderung labil dalam menyikapi suatu hal. Hal tersebut dapat menjadi penyebab perempuan dewasa memiliki sikap yang buruk terhadap KDRT. Berbeda dengan perempuan dewasa pada rentang usia 33 sampai 39 tahun yang diidentifikasi Levinson sebagai masa tenang. Perempuan dewasa pada masa ini telah memiliki stabilitas yang lebih besar sehingga memiliki ketenangan dalam bertindak dan menyikapi KDRT. Hal ini sesuai dengan penelitian yang dilakukan oleh Kim-goh dan Baello (2008) tentang sikap terhadap KDRT pada komunitas imigran Korea dan Vietnam yang menemukan bahwa responden yang lebih muda memiliki sikap yang lebih negatif terhadap KDRT dibandingkan dengan responden yang lebih tua.

\section{Pengetahuan dan Sikap Responden tentang KDRT Berdasarkan Tingkat Pendidikan}

Hasil penelitian menunjukkan bahwa pengetahuan baik tentang KDRT dimiliki oleh mayoritas responden lulusan SD (30,4\%) sedangkan pengetahuan kurang dimiliki responden lulusan perguruan tinggi (66,8\%). Hal ini tidak sesuai dengan pendapat Notoatmodjo (2007) yang menyatakan bahwa umumnya seseorang yang memiliki pendidikan lebih tinggi akan mempunyai pengetahuan yang lebih 
luas dibandingkan dengan seseorang yang tingkat pendidikannya lebih rendah. Pendapat Notoatmodjo didukung penelitian yang dilakukan Ameh dan Abdul (2004) tentang KDRT pada wanita hamil di Zaira, Nigeria yang menyebutkan bahwa dari 270 wanita yang mendatangi klinik antenatal, 140 orang (79\%) diantaranya berpendidikan lebih dari SMP dimana 55,6\% memiliki pengetahuan tentang KDRT sedangkan $44,4 \%$ tidak memiliki pengetahuan tentang KDRT. Hal ini menunjukkan bahwa idealnya perempuan dewasa dengan pendidikan lebih tinggi memiliki pengetahuan yang baik. Kontradiksinya adalah pendidikan formal tidak dapat menjadi satu-satunya faktor yang memengaruhi pengetahuan tentang KDRT mengingat KDRT merupakan tema sosial yang belum ada dalam kurikulum pendidikan.

Hasil penelitian menunjukkan bahwa sikap baik terhadap KDRT dimiliki oleh mayoritas responden lulusan perguruan tinggi (60\%) dan sikap buruk dimiliki mayoritas responden lulusan SMA (65,8\%). Hal ini sesuai melalui pernyataan Rahayuningsih (2008) dimana lembaga pendidikan berfungsi meletakkan dasar pengertian dan konsep moral dalam diri individu sehingga dapat menghasilkan pemahaman baik dan buruk, salah atau benar, yang menentukan sistem kepercayaan seseorang. Hal tersebut sesuai dengan penelitian mengenai sikap terhadap KDRT yang di lakukan oleh Rohmah (2004, dalam Hanum, 2006). Penelitian tersebut menyebutkan ada keterkaitan antara tingkat pendidikan korban kekerasan dalam rumah tangga dengan atribusi yang dilakukan dimana korban kekerasan yang berpendidikan tinggi (SMA ke atas) memiliki kecenderungan untuk menilai penyebab kekerasan yang dialami berdasarkan rasional. Perempuan lulusan perguruan tinggi telah menggunakan rasional untuk melakukan perlawanan dan melaporkan tindak KDRT jika hal tersebut terjadi.

\section{Pengetahuan dan Sikap Responden tentang KDRT Berdasarkan Pekerjaan}

Hasil penelitian menunjukkan bahwa mayoritas responden yang memiliki pengetahuan baik (25\%) dan kurang (75\%) tentang KDRT adalah responden yang bekerja di luar rumah. Hal ini menjadi kontradiksi karena dalam satu karakteristik terdapat dua kategori yang berlawanan. Mayoritas perempuan bekerja memiliki pengetahuan kurang karena perempuan yang bekerja memiliki beban kerja tambahan. Hal tersebut sesuai dengan pernyataan Astuti (2008) bahwa beban kerja menjadi dua kali lipat terlebih bagi perempuan yang bekerja di luar rumah karena selain bekerja, mereka juga harus bertanggung jawab untuk keseluruhan pekerjaan rumah tangga. Beban kerja ganda tersebut membuat perempuan yang bekerja di luar rumah tidak sempat mengakses informasi mengenai KDRT sehingga mayoritas memiliki pengetahuan kurang. Berbeda dengan perempuan bekerja yang memiliki pengetahuan baik karena kemungkinan memiliki waktu kerja yang tidak terlalu padat sehingga dapat mengakses informasi di sela waktu kerja. Perempuan bekerja tersebut juga memiliki pergaulan yang lebih luas sehingga dapat memperoleh informasi tambahan mengenai KDRT dari rekan kerja. Hal ini sesusai dengan penelitian yang dilakukan Al Hibri dkk. (2001) yang menyebutkan bahwa wanita karir atau wanita yang bekerja umumnya adalah wanita yang berpendidikan cukup tinggi, mempunyai tingkat energi tinggi, dan pada umumnya menikmati kesehatan yang baik. Tingkat energi tinggi yang dimiliki sebagian perempuan bekerja yang memiliki pengetahuan baik digunakan untuk mengakses sumber informasi mengenai KDRT.

Hasil penelitian juga menunjukkan bahwa $64 \%$ responden ibu rumah tangga memiliki pengetahuan kurang dan hanya 23,6\% memiliki pengetahuan baik. Hal ini terjadi karena konsep ibu rumah tangga pada perempuan yang mengacu pada suatu proses ideologis dan materiil dimana perempuan secara dominan didefinisikan sebagai ibu rumah tangga dengan tugas yang tidak dibayar untuk melayani reproduksi tenaga kerja dalam rumah tangga (Meis, 1986, dalam Astuti, 2008). Ibu rumah tangga di terlalu sibuk mengurus keperluan rumah tangga sehingga tidak memiliki waktu untuk 
mencari tahu mengenai KDRT. Ibu rumah tangga di kawasan rural ini juga memiliki keterbatasan akses terhadap media informasi sehingga tidak memiliki pengetahuan tambahan mengenai KDRT. Media sebagai sumber informasi dapat mempengaruhi pengetahuan yang dapat diperoleh dari buku maupun media massa seperti radio, televisi, majalah, dan koran (Notoatmodjo, 2007). Kurang sadar akan pentingnya media informasi untuk menambah pengetahuan mengenai KDRT juga membuat ibu rumah tangga memiliki pengetahuan kurang. Hal tersebut sesuai dengan penelitian yang dilakukan Sari (2008) pada ibu rumah tangga di Kabupaten Langkat yang menunjukkan bahwa sebanyak 33 orang (55,9\%) dari 59 orang responden kurang mengetahui dampak kekerasan.

Hasil penelitian ini menunjukkan sikap baik terhadap KDRT dimiliki mayoritas responden perempuan yang bekerja di luar rumah (50\%) dan sikap buruk dimiliki mayoritas responden ibu rumah tangga (55,1\%). Ibu rumah tangga memiliki sikap buruk terhadap KDRT karena merasa bergantung pada suami, terutama dari segi finansial. Kurangnya sumber-sumber ekonomi membuat perempuan sangat bergantung pada suaminya sehingga rentan terhadap kekerasan, merasa kesulitan dalam mengeluarkan diri dari kekerasan, dan menerima dengan pasrah segala bentuk kekerasan yang dialaminya (Astuti, 2008; Kapoor, 2000). Hal ini berbeda dengan perempuan bekerja yang memiliki sikap baik terhadap KDRT karena telah memiliki penghasilan sendiri sehingga tidak merasa bergantung pada suami. Hal tersebut sesuai dengan penelitian Astuti dkk. (2006) yang menunjukkan bahwa ratarata sikap terhadap kekerasan suami pada istri yang bekerja sebesar $71,6 \%$ berada pada kategori sikap positif bahwa perempuan bekerja menunjukkan kecenderungan sikap untuk menolak tindak kekerasan yang terjadi dalam rumah tangga yang dilakukan suami.

\section{Pengetahuan dan Sikap Responden tentang KDRT Berdasarkan Status Pernikahan}

Hasil penelitian menunjukkan pengetahuan baik dimiliki oleh mayoritas responden janda (40\%) sedangkan pengetahuan kurang dimiliki mayoritas responden menikah $(64,4 \%)$. Pengetahuan yang kurang tersebut dapat terjadi karena perempuan menikah menganggap KDRT hanya merupakan kekerasan fisik yang dilakukan suami terhadap istri. Kekerasan dalam bentuk verbal dan emosional biasanya tidak dianggap kekerasan pada beberapa budaya dan negara tertentu (Astuti, 2008). Hal ini sesuai dengan penelitian yang dilakukan pada perempuan menikah di area pedesaan di China oleh Zhao et. al (2006) dengan hasil perempuan yang sudah menikah memiliki pengetahuan relatif sedikit tentang KDRT dan $75,2 \%$ wanita bahkan tidak tahu apa kekerasan dalam rumah tangga yang dimaksud dan beberapa wanita menderita KDRT tetapi tidak mengetahui implikasinya. Hal ini berbeda dengan janda yang memiliki pengetahuan baik tentang KDRT yang diperoleh dari pengalamannya pernah membina rumah tangga. Notoatmodjo (2007) menyatakan bahwa pengalaman dapat diperoleh dari pengalaman sendiri maupun orang lain dan dapat memperluas pengetahuan seseorang.

Hasil penelitian juga menunjukkan sikap baik terhadap KDRT dimiliki oleh mayoritas responden menikah (46\%) sedangkan sikap buruk dimiliki mayoritas responden janda (60\%). Perempuan yang menjanda memiliki sikap buruk karena pengalaman pernah berumah tangga. Perempuan tersebut memiliki kemungkinan mengalami KDRT selama masa perkawinan dan memilih untuk bercerai namun perceraian tersebut mendapat pertentangan dari masyarakat. Hal ini sesuai dengan pendapat Kurniasih (2007) bahwa masyarakat masih memandang negatif terhadap janda akibat perceraian dibanding janda karena ditinggal mati suami. Pengaruh pengalaman dan pandangan masyarakat yang membebani perempuan berstatus janda menjadikannya menyesal atas perceraian dan seharusnya menerima kekerasan sebagai hal yang wajar. 


\section{Kesimpulan dan Saran}

Kesimpulan yang diperoleh dari penelitian ini adalah Mayoritas perempuan dewasa di Desa Sukoharjo IV Kabupaten Pringsewu Lampung memiliki pengetahuan kurang (64,5\%) tentang KDRT. Pengetahuan kurang kemungkinan terjadi karena kurangnya sumber informasi, tidak memiliki pengalaman, keyakinan yang salah, finansial yang terbatas, dan kesadaran yang kurang untuk mencari informasi tentang KDRT.

Mayoritas perempuan dewasa di Desa Sukoharjo IV Kabupaten Pringsewu Lampung memiliki sikap buruk (54,8\%) tentang KDRT. Pengalaman orang lain yang dianggap dekat, budaya patriarki, dan subordinasi yang ditanamkan serta keterbatasan akses media massa dimungkinkan menjadi faktor yang memengaruhi sikap buruk tentang KDRT.

Mayoritas perempuan dewasa memiliki pengetahuan baik pada rentang usia 40 sampai 60 tahun $(27,3 \%)$, lulusan SD (30,4\%), bekerja di luar rumah (25\%), dan janda $(40 \%)$, sedangkan pengetahuan kurang dimiliki mayoritas perempuan dewasa pada rentang usia 33 sampai 39 tahun (70,8\%), lulusan perguruan tinggi $(66,8 \%)$, bekerja di luar rumah $(75 \%)$, dan menikah $(64,4 \%)$. Mayoritas perempuan dewasa memiliki sikap baik pada rentang usia 33 sampai 39 tahun $(54,2 \%)$, lulusan perguruan tinggi (60\%), bekerja di luar rumah (50\%) dan menikah (46\%), sedangkan sikap buruk dimiliki mayoritas perempuan dewasa pada rentang usia 28 sampai 32 tahun $(61,5 \%)$, lulusan SMA $(65,8 \%)$, ibu rumah tangga $(55,1 \%)$, dan janda $(60 \%)$.

Saran yang dapat diberikan dari penelitian ini adalah perempuan dewasa diharapkan lebih aktif dalam mencari sumber informasi mengenai KDRT baik melalui media massa maupun pelayanan kesehatan setempat untuk meningkatkan pengetahuan dan sikap baik.

Perempuan dewasa dari kategori usia yang telah memiliki pengetahuan dan sikap baik diharapkan dapat memberikan pemahaman tentang KDRT kepada orang-orang di sekitarnya. Perempuan lulusan perguruan tinggi diharapkan lebih terbuka terhadap informasi mengenai KDRT.

Pemberian penyuluhan kesehatan perempuan terkait KDRT diberikan merata dan dengan pertimbangan waktu yang dapat diikuti oleh perempuan dewasa yang bekerja di luar rumah maupun ibu rumah tangga serta mencakup sosialisasi mengenai Undang-Undang Republik Indonesia Nomor 23 Tahun 2004 tentang Penghapusan Kekerasan dalam Rumah Tangga agar memiliki pemahaman yang valid mengenai KDRT.

\section{Daftar Pustaka}

Al-Hibri, A. dkk. (2001). Wanita dalam masyarakat Indonesia: Akses, pemberdayaan, dan kesempatan. Yogyakarta: Sunan Kalijaga Press.

Ameh, N. \& Abdul, M. A. (2004). Prevalence of domestic violence amongst pregnant women in Zaria, Nigeria. Annals of African Medicine Vol. 3, No. 1; 2004: 4-6. Diunduh dari www.bioline.org.br/pdf?am04002 pada 26 Juni 2012

Arikunto, S. (2004). Evaluasi program pendidikan. Jakarta: PT Bumi Aksara.

Astuti, D. A. dkk. (2006). Hubungan antara kemandirian dengan sikap terhadap kekerasan suami pada istri yang bekerja di Kelurahan Sampangan, Kecamatan gajah Mungkur, Kota Semarang. Jurnal psikologi Universitas

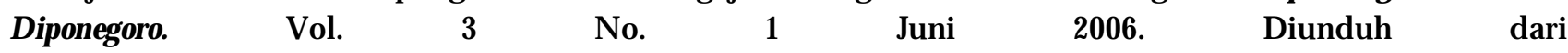
www.ejournal.undip.ac.id/index.php/psikologi/article/kiew/691 
Astuti, T.M.P. (2008). Konstruksi gender dalam realitas sosial. Semarang: Universitas Negeri Semarang Press

Bobak, Lowdermilk, \& Jensen. (2005). Buku ajar keperawatan maternitas E/4 (Maria A. Wijayarini dan Peter I. Anugerah, Terjemahan). Jakarta: Penerbit Buku Kedokteran EGC

Dahlan, M. S. (2010). Seri evidence based medicine. Jakarta: CV Sagung Seto.

DeLaune, S.C. \& Ladner, P. K. (2002). Fundamentals of nursing standards and practice (2nd ed). New York: Delmar.

Fachrina \& Anggraini, N. (2007). Kekerasan terhadap perempuan dalam keluarga pada masyarakat Minangkabau kontemporer. Padang: Laporan Penelitian Universitas Andalas.

Guilford, J. P. \& Fruchter, B. (1978). Fundamental Statistics in Psychology and Education. Singapore : McGraw-Hill.

Hansson, P., Rönnlund, M., Juslin, P., \& Nilsson, L. (2008). Adult age differences in the realism of confidence judgments: Overconfidence, format dependence, and cognitive predictors. Psychology and Aging, 23(3), 531544. doi:10.1037/a0012782

Hanum, F. (2006). Perempuan dan kekerasan dalam rumah tangga. Sarathi Vol.13 No. 2 Juni 2006.

Hastono, S. P., \& Sabri, L. (2010). Statistik kesehatan. Jakarta: PT RajaGrafindo Persada.

Kapoor, S. (2000). Domestic violence against women and girls. Diunduh dari http://www.unicefirc.org/publications 213 pada 27 juni 2012

Kim-goh, M., \& Baello, J. (2008). Attitudes toward domestic violence in korean and vietnamese immigrant communities: Implications for human services. Journal of Family Violence, 23(7), 647-654. doi:10.1007/s10896008-9187-2

Kementrian Negara Pemberdayaan Perempuan. (2010). Kebijakan perlindungan perempuan. Diunduh dari www.menegpp.go.id/aplikasidata/index.php?option=com pada tanggal 8 Maret 2012.

Kolibonso, R. S. (2010). Penegakan hukum kejahatan kekerasan dalam rumah tangga. Diunduh dari

http:/wwww.djpp.depkumham.go.id hukum-pidana/677-penegakan-hukum-kejahatan-kekerasan-dalamrumah- tangga.html pada tanggal 8 Maret 2012.

Kurniasih, N. (2007). Kajian yuridis sosiologis terhadap kekerasan berbasis gender. Retrieved: www.uninus.ac.id/...KAJIAN\%20YURIDIS\%20 pada tanggal 8 Maret 2012.

Luhulima, A. S. (2000). Pemahaman bentuk-bentuk tindak kekerasan terhadap perempuan dan alternatif pemecahannya. Jakarta: Alumni

Mardiana, E. (2012). Pengetahuan perempuan jabar tentang KDRT masih minim. Diunduh dari http:/bandung.detik.com/read/2012/02/19/124557/1846045/486/pengetahuan-perempuan-jabar-tentang-kdrtmasih-minim pada tanggal 30 Juni 2012.

Marshall, G. A. \& Furr, L. A. (2010). Factors that affect womens attitudes toward domestic violence in turkey. Violence and Victims, 25(2), 265-77. http://search.proquest.com/docview/287961419?accountid=17242

Meiyenti, S. (1999). Kekerasan terhadap perempuan dalam rumah tangga. Yogyakarta: Pusat Penelitian Kependudukan Universitas Gadjah Mada.

Munaf, S. (2001). Evaluasi pendidikan fisika (individual textbook). Bandung: Jurusan Pendidikan Fisika FPMIPA UPI

Notoatmodjo, S. (2007). Promosi Kesehatan dan Ilmu Perilaku. Jakarta: Rineka Cipta.

Notoatmodjo, S. (2010). Promosi kesehatan: Teori dan aplikasi (edisi revisi). Jakarta: PT. Rineka Cipta.

Notoatmodjo, S. (2010). Metodologi penelitian kesehatan. Jakarta: PT. Rineka Cipta.

Novitasari, Y. (2010). Faktor-faktor yang melatarbelakangi terjadinya Kekerasan Dalam Rumah Tangga (Studi kasus KDRT di desa Rasabou Kecamatan Sape Kabupaten Bima Nusa Tenggara Barat). Bima: Laporan Penelitian.

Polit D. F \& Beck, T. C. (2006). Essential nursing research methods appraisal utilization. Philadelphia: Lippincott 
William \& Wilkins.

Posyandu Matahari \& Griya Bhara Wira. (2012). Data PUS dan WUS RW 10, Kelurahan Sukamaju Baru, Kecamatan Tapos, Kota Depok. Depok: Arsip Posyandu.

Potter, P.A \& Perry, A. G. (2006). Fundamental of nursing: concept, theory and practice. Jakarta: Penerbit Buku Kedokteran EGC.

Rahayuningsih, S., U. (2008). Sikap (attitude). Diunduh dari www.nurul q.staff.gunadarma.ac.id/Downloads/files 9095 bab1 pada tanggal 8 Maret 2012.

Risna, et. al. (2009). Tingkat pengetahuan ibu rumah tangga tentang Kekerasan Dalam Rumah Tangga (KDRT) terhadap istri di RW 08 Kelurahan Pondok Cina, Kecamatan Beji, Kota Depok. Depok: Laporan Penelitian UI

Sari, D.K. (2008). Gambaran pengetahuan ibu tentang kekerasan terhadap perempuan dalam rumah tangga di dusun V Desa Sambi Rejo Kec. Stabat Kab. Langkat tahun 2008. Diunduh dari www.repository.usu.ac.id bitstream/123456789/23856/6/Cover.pdf pada tanggal 8 Maret 2012.

Setiawan, N. (2007). Penentuan ukuran sampel memakai rumus slovin dan tabel krejcie-morgan: telaah konsep dan aplikasinya. Bandung: Skripsi S1.

Stuart, G., W. and Laraia, M., T. (2005). Principles and practice of psychiatric nursing, $8^{\text {th }}$ ed. St. Louis: Elsevier Mosby.

Tarida, S. (2011). Kekerasan Seksual dalam Catatan Tahunan Komnas Perempuan http:/www.komnasperempuan.or.id/2011/08 kekerasan-seksual-dalamperempuan-tahun-2011/ pada tanggal 8 Maret 2012.
Tahun 2011. Diunduh dari catatan-tahunan-komnas-

Triwijati, E. (2007). Memahami kekerasan dalam rumah tangga dan menanggulanginya. Jakarta: Program Pasca Sarjana Universitas Indonesia.

Videback, S. (2008). Psychiatric mental health nursing. Philadelphia: Lippincott William \& Wilkins.

Zhao, F. M., et.al (2006). Investigation on the patterns and knowledge regarding domestic violence among married woman in rural areas of China. Chinese Journal of Epidemiology, 27 (08): 664-668. Diunduh dari http://www.ncbi.nlm.nih.gov/pubmed/17172104 pada tanggal 26 Juni 2012. 
